\title{
Correction to: Methodological remarks on soft topology
}

\author{
Milan Matejdes ${ }^{1}$ (D)
}

Published online: 16 February 2021

(C) Springer-Verlag GmbH Germany, part of Springer Nature 2021

\section{Correction to: Soft Computing}

https://doi.org/10.1007/s00500-021-05587-7

The family name and given name was incorrectly published.

The correct family name is Matejdes and given name is Milan.

The original article has been corrected.

Publisher's Note Springer Nature remains neutral with regard to jurisdictional claims in published maps and institutional affiliations.

The original article can be found online at https:// doi.org/10.1007/s00500-021-05587-7.

Milan Matejdes

milan.matejdes@truni.sk

1 Department of Mathematics and Computer Science, Faculty of Education, Trnava University in Trnava, Priemyselná 4, 91843 Trnava, Slovak Republic 